\title{
Modernization, Dependency and Structural Adjustment Development Theories and Africa: A Critical Appraisal
}

\author{
Alfred G Nhema (Corresponding author) \\ Department of Political and Administrative Studies, University of Zimbabwe \\ P.O. Box MP 167, Mount Pleasant, Zimbabwe
}

Tawanda Zinyama

Department of Political and Administrative Studies, University of Zimbabwe

P.O. Box MP 167, Mount Pleasant, Zimbabwe

Received: February 18, 2016

Accepted: February 23, 2016 Published: March 7, 2016

doi:10.5296/ijssr.v4i1.9040

URL: http://dx.doi.org/10.5296/ijssr.v4i1.9040

\begin{abstract}
This article seeks to review the early development theories that have dominated the development path in Africa over a number of decades. First, the paper reviews the modernisation theory which dominated the literature on development theory in the $1950 \mathrm{~s} / 60 \mathrm{~s}$ as the former colonies attained their independence. Second, the paper examines the dependency theory which was a critical response to the modernisation paradigm. Third, the paper assesses the nature and form of neo liberal prescriptions that came to be known as Structural Adjustment Programmes (SAPs) offered by the International Monetary Fund (IMF) and the World Bank (WB) from the 1980s to the 1990s. Finally, the paper explores the relevance and impact of the identified development theories to the development of Africa.
\end{abstract}

Keywords: Africa, development theory, modernisation theory, dependency theory, structural adjustment programmes

\section{Introduction}

Development studies emerged as a post-war World War II challenge designed to help poorer countries catch up with the richer countries in terms of economic development. In everyday speech and in intellectual circles, collective nouns abound to describe the poorer countries as a whole. The poor countries are variously described as the "developing world", "the 
underdeveloped world", "the backward countries", the "Third World", the "South", or "emerging countries" (Greig, Hulme and Turner, 2007:43). These descriptions provide a sense of "us and them" or- translated into the language of development - a sense of who has achieved the goal of "progress and modernity" (Greig et al., 2007:53) and who "needs help" (Power, 2003:99). According to Escobar (1995: 30), as soon as the poorer countries achieved independence, they were "infantilized" by Western academic and political discourses. This provided the pretext for the West to come to the poor countries' "salvation" through approaching them as a "child in need of adults' guidance."

This paper seeks to review the major development theories that have dominated the development path in Africa over the past five independence decades. First, the paper reviews the modernisation theory which dominated the literature on development theory in the $1950 \mathrm{~s} / 60 \mathrm{~s}$ as the majority of the former colonies attained their independence. Second, the paper analyses the dependency theory which was a critical response to the modernisation paradigm. Third, the paper explores the nature and form of Structural Adjustment Programmes and how the programmes impacted on the development of Africa. The final focus of the paper is on the examination of the relevance of the various identified developmental theories to Africa.

\section{Modernisation Theory}

The modernisation theory argues that development involves facilitating the post-colonial world along the path to progress towards modernity. The route from traditional society to modern society was named the "process of modernisation" (Sylvester, 1999). Modernisation is defined as "the process of social change whereby less developed societies acquire characteristics common to more developed societies" (Lerner, 1972:386). The key tenets of the modernisation theory include:

- First, progress involves breaking the chains of traditional society and moving towards the enlightened space of modernity, where individuals increasingly take control of their social and physical environment through an ever-expanding appreciation of science and experienced high levels of material affluence;

- Second, this process could be observed and measured in a scientific manner now that social scientists had a historical model - the modernisation of the West - which acted as a successful prototype that the object of inquiry - the poorer world - could emulate;

- Third, while the 'original transition' to modernity was mainly seen as a result of endogenous forces, the existence of the prototype could help promote development and modernisation through exogenous assistance;

- Fourth, methodologically, this framework presented a 'dualist' model of history that measured the change from 'ideal type' poles of tradition and modernity; and compared and contrasted the contemporary reality of poorer countries with the history of the Western industrialised world. As Rapley (2002:15) notes, this methodology required the researcher to 'identify the conditions that had given rise to development 
in the first world and specify where and why these were lacking in the Third World" (Greig et al., 2007: 74).

Another supplementary characteristic of modernisation theory is that it offers an approach to development that acknowledges the complex interaction between social, cultural, political and economic life (Lerner, 1972: 388). It stresses how changes in one part of a social structure have repercussions for other parts. Inferred here is that the developmental transformation requires simultaneous attention to political structures, technology, cultural institutions and individual behaviour. It is striking to note that the modernisation theory explains the prevalence of extreme poverty in poorer countries, primarily, as a consequence of endogenous forces. The traditional social structures are alleged to lack certain developmental ingredients - or "change agents - that had propelled the processes of modernisation formation in the West" (Easterly, 2002; Greig et al., 2007).

The post-war modernisation crusade occurred during the Cold War period. All developing countries were affected by the geo-political struggle and found themselves distracted by military and political considerations, diverting valuable energy away from the more fundamental tasks of economic and institutional development (Greig et al, 2007:78). However, these military considerations were important because modernisation theorists construed communism as a "virus" that was attracted to the problems that developing countries confronted at the earlier stages of development.

Therefore, it was argued that the process of modernisation would overcome the inequality gap between the richer and poorer countries through the latter catching up with the former. This prompted Greig et al. (2007) to conclude that modernisation involves a progress of global "homogenisation" (Greig et al., 2007:79) as the poorer countries adopt the values that earlier developers had found consistent with modernity. Furthermore, the relations between the richer and poorer countries were understood to be reciprocal and beneficial.

Notwithstanding the positives of the modernisation theory, it has encountered a range of methodological, theoretical and ideological criticisms. There are doubts concerning the extent to which past observations relating to Western culture could be used to predict future developments in other cultures. In the process, modernisation is being construed as "westernisation" (Pieterse, 2004). It was, consequently, contaminated with "ethnocentricism" (Wright, 2005). Modernisation theorists tend to present western capitalism as a relatively conflict-free, classless, democratic and egalitarian arrangement. Some researchers view modernisation theory as an ideological screen for post-war neo-colonial dominance. From this conceptualisation, westernisation is construed as an instrument of imperialism.

Other critics were concerned that the path from tradition to modernity was not as straight forward as modernisation theorists suggested. Yet, observation of the modernisation process suggests in many cases that social conflict was endemic and pervasive, that inequalities between and within countries were sharpening (Werthenlm, 1974:317). The modernisation theory ignores issues of power and inequalities within and between societies (Webster, 1984:55). The inattention to the concept of power is a characteristic feature of modernisation theory. 
The Marxist perspective contends that the more advanced nations hold out a mirror to the poorer countries, showing them "an image of their own future." The key difference between modernisation theory and Marxism was that whereas the former viewed the age of high mass consumption as the pinnacle of history, for Marx, the pre-history of humankind would only come to an end once the contradictions of capitalism had been transcended through a subsequent proletarian revolution leading eventually to communism.

Marx was very conscious of the double-edged nature of capitalist development. It brings progress as well as misery. Marx and Engels (1969) tend to discuss premodern and non-European cultures as primitive, historically insignificant, obscurantist and static, whereas they view the West as possessing rationality, enlightenment and dynamism.

These shortcomings of the modernisation theory led to the emergence of an alternative development theory in the form of the dependency theory. The expansive discussion of this dependency theory follows below.

\section{Dependency Theory}

A more direct challenge to the modernisation theory emerged in the 1960s and 1970s in the form of the dependency theory. This theory owes its origin to the writings of Baran (1957), Prebisch (1971) and Frank (1971). Drawing on the notion of inequality between the industrial nations and the non-industrial world (Prebisch, 1971), dependency theory refers to the former as the "core" and the latter as the "periphery." Contrary to modernisation theory, dependency theory views development from the perspective of the impact of exogenous forces on the periphery.

In the dependency theory, capitalism is understood as a world system that contains an inherent core-periphery duality or "metropolis-satellite" concept ((Frank, 1971) that determines the developmental potentialities of different countries. Dependency is defined as a "situation in which a certain number of countries have their economy conditioned by the development and expansion of another" (Dos Santos quoted in Valenzuela and Valenzuela, 1978:544). Thus, the possibility of development is determined by the relationship of exploitation that exists between the "core and periphery."

The dependency theory, furthermore, locates the dynamics of exploitation in the transfer of the periphery's resources to the core through a process of unequal exchange on the international market (Emmanuel, 1972). The core accumulates its resources for modern development through exploiting periphery countries, consequently under developing them. Increasingly throughout the twentieth century, terms of trade moved against primary products in favour of technologically more sophisticated goods. This unequal exchange acted as a further drain on the surpluses of the periphery and inhibited the process of capital accumulation (ILO, 2004:30).

The dependency approach is consistent with the earlier Marxist theories of imperialism that focused on how the exploitation of the colonial labour force reduced the costs of commodities thereby cheapening the cost of reproducing the working class in the advanced countries as well as keeping the core working class politically more pliant (Larrain, 1989:118). The 
logical consequence was that exploited classes in the periphery would have to rely primarily on their own resources to overthrow the oppressive state structure that tied them to the world capitalist system. Only then could the exploitative links that chained them to the world system be severed and progressive policies implemented for the benefit of national development and popular demand (Frank, 1974; Amin, 1985). For the dependency theorists, the experience of the developed countries cannot be used as a model to follow because it is their very development which nurtures underdevelopment in the periphery. The major question is not why the developing countries are still poor but how they have become poor.

However, dependency theory is often accused of presenting the global economy as "a zero-sum or negative-sum whereby the gains of the core came at the expense of the periphery" (Hoogvelt, 1997:4). Ultimately, however, dependency theory draws more pessimistic conclusions than modernisation theory about the possibility of peaceful and evolutionary development. As Wallerstein (2004:10) notes, modernisation theory suggests that the "most developed" state could offer itself as a model for the "less developed" states, urging the latter to engage in a sort of mimicry and promising a higher standard of living and a more liberal government structure (political development) at the end of the rainbow."

The dependency theory has been criticised for inadequately accounting for unexpected capitalist successes in the periphery. If capitalism caused peripheral underdevelopment, then dependency theory had to explain the spectacular success of industrialisation and economic growth that the Newly Industrialising Countries (South Korea, Taiwan, Singapore, Hong Kong) experienced during the 1970s and 1980s (Harris, 1987; Lipietz, 1988). In these circumstances, exogenous links with core capitalism especially the United States of America (USA) did not produce standard peripheral underdevelopment as pronounced in Africa.

The structural model of development offered by the dependency theory also contains another theoretical trap. Critics from both the left and the right have pointed out that 'imperialism' appears as "the root of all evil" (d'Souza, 2002:110) or "the beast of the apocalypse" (Lipietz, 1988:17) or a "monodiabolism" (Olsen, 1982:177). In this model, the periphery is construed as a passive respondent to forces centred elsewhere and this restricts its options and its room to manoeuvre. It denies peripheral countries agency, allowing scope for a "victim mentality" to emerge while "fostering a morbid propensity to find fault with everyone but oneself" (Landes, 2002:328).

Though both the modernisation and dependency theories have noticeable blemishes, it is striking to note that both have assigned a significant role to planning and co-ordinated assistance in the development project. If one follows the dependency thesis's prescription for development malaise in Africa and the South at large, the questions then are: How then can this dependency predicament be broken. One theorist has argued that it is indispensable that the peoples and the leaders of the South free themselves from their way of discerning and thinking that "interiorises dependency and that they cease to believe that aid constitutes the condition for the development of their societies" (Amin, 2011).

As it became apparent that the modernisation and dependency theories had failed to achieve the developmental goals and objectives they prescribed, development theorists came up with 
the neo-liberalism and market-oriented approaches. The next section discusses the fundamental arguments that underpin the neo-liberalism model to development.

\section{Neo-liberalism and Market-oriented Development}

By the late 1980s, the developmental path promoted by the United Kingdom and the United States of America (USA) was publicised not as a promising path leading to greater quality and freedom, but as the only path pointing in that direction. This came to be known as the TINA principle, after the former British Prime Minister, Margaret Thatcher, had proclaimed that "There Is No Alternative" but to follow her monetarist reform path.

The central argument of the neo-liberalism framework is that underdevelopment results from poor resource allocation due to incorrect pricing policies and too much state intervention by developing-nation governments. The neo-liberals argue that through the promotion of free markets, free trade and the elimination of excessive government controls, economic growth and efficiency of the market will be stimulated. Contrary to the claims of the dependency theorists, the liberals advocate for the promotion of free markets within the context of permissive governments that allow the "magic of the market place" and the "invisible hand" of market policies to guide resource allocation and stimulate development. They point to the success of countries like South Korea, Taiwan and Singapore as 'free market' examples and to the failures of the public-interventionist economies of Africa and Latin America (Bauer, 1984; Lal, 1985; Taylor, 1997).

Neo-liberalism was advocated and supported by the IMF and the World Bank commonly referred to as the international financial institutions (IFIs). Dependency theorists argue that these institutions tightened the bonds of peripheral exploitation by the core. Unequal exchange fuelled debt, which then led to a vicious cycle of repayments, external trade difficulties and further debt burdens. The IFIs sought to restructure the economies of the poorer nations and undertake the interrelated tasks of meeting debt obligations, liberalising economies and encouraging greater openness to international trade (Wachtel, 1986:125). Their policy advice aimed at generating "high quality growth", defined as sustained growth that lay the foundations for future development. The leverage that the IFIs use to achieve compliance from the poorer indebted countries involves withholding future loans until the appropriate policy medicine is administered. For instance, the prescription offered by the IMF and WB around 1980s/1990s that came to be known as Structural Adjustment Programmes (SAPs) stipulated tighter fiscal control and liberal economic reforms within poorer countries. These reforms were "another nail in the coffin of post-war state-led development" (Rapley, 2002).

The SAPs remained true to the prototype model of development. As Gray (2004:87) describes it, there was "only one route to modernity and the IMF had resolved that it be followed everywhere (Hertz, 2004:112). The prototype/emulator relationship inherent within this model has also been noted by Sachs (2005:81): "Be like us (or what we imagine ourselves to be - free market oriented, entrepreneurial, fiscally responsible) and you, too, can enjoy the riches of private sector-led economic development." 
Emulation required the pursuit of the "Washington Consensus" model focused on the following policies:

- Controlling inflation through wage controls;

- Privatisation of publicly owned enterprises;

- Balancing state budgets through reducing government expenditure;

- Eliminating or reducing state subsidies on basic goods;

- Generation of foreign exchange through export-oriented industries rather than support for import substitution; and

- Elimination of controls on foreign capital.

Whether the IFIs policies are considered a success or failure depends on one's vantage point (Pieterse, 2004:12). Despite acknowledging some mistakes, the IFIs retain confidence that their prescriptions remain the best hope for poorer nations to alleviate their poverty, catch up with the wealthier nations and bridge the inequality gap (IMF, 1998). They also stress that the SAPs cannot be held responsible for the conditions that most indebted nations subsequently found themselves in because few signatories to SAPs had the courage to fully implement their policy prescriptions (Bhagwati, 2004). Once SAPs conditionalities were agreed, complex cat-and-mouse games were played between Ministries of Finance and the IMF/WB about how to measure structural change and re-negotiate conditions (Easterly, 2002).

Most critics of the IFIs have focused attention on the impact that their prescriptions have upon inequalities between countries and within countries. If global inequality was labelled a problem of unequal exchange prior to the 1980s, in the new millennium this has been compounded by "debt-peonage" (Hoogvelt, 1997:50). This form of control over poorer countries has the advantage that it does not require direct administration - only arms-length control through "market discipline" and "conditionalities" Amin, 2009; Hertz, 2004; Kothari, 2002). Minogue (2002:122) suspects that demands for "good governance" mark "a new phase of surveillance and control on the part of international capital."

Since the late 1990s, two potentially significant changes have occurred at the IMF and World Bank. The first relates to their statements about shifting to a post-Washington Consensus approach that recognises the need for state action as well as market forces. This thinking leads to the avoidance of the one size fits all naivety of the structural adjustment era and seeks to ensure that reforms are "owned" by recipient countries and not just the IFIs. The second concern regards the declared prioritisation of poverty-reduction by both organisations. The main instrument of the IMF is now the Poverty Reduction and Growth Facility Loan (PRGFL) while that of the World Bank is the Poverty Reduction Strategy Credit (PRSC). Both require that governments prepare national poverty reduction strategies (PRSs) in consultation with their civil societies before loans can be granted. Even Fukuyama (2006:109) has acknowledged that the disappointing results of pro-market policies over the 1990s had discredited neo-liberalism in many poorer countries by the turn of the new millennium. 
In the years preceding the $50^{\text {th }}$ anniversary of the IMF, a global push was initiated through the "Jubilee" campaign to restructure or forgive the indebtedness of poorer nations. Among the Jubilee demands that remain relevant in the new millennium are:

- Make the IMF and the World Bank completely open and accountable;

- Support development programmes that are equitable, sustainable and participatory;

- End all environmentally lending;

- Scale back the Washington Consensus and redirect financial resources into a variety of development assistance alternatives; and

- Cancel all outstanding debt owed to the IMF and the World Bank by the world's poorest countries (Greig et al., 2007: 128).

In 2005, the Jubilee campaign culminated in the Live 8 music concerts held in various countries whose leaders were attending a G8 meeting at Gleneagles, Scotland. The concerts were designed to raise awareness of three interrelated development demands: 'drop the debt', 'make trade fair' and 'make poverty history.' These demands were echoed in the Millennium Development Goals, agreed to by the world's leaders at the United Nations (UN) in 2000.

\section{Modernization, Dependency and Structural adjustment programmes theories and their relevance to the African Development Experience}

In the early 1960s, when an increasing number of African countries were emerging from their colonial status, a stated goal of the political leadership in these newly independent countries was rapid economic growth. During that time it made sense to speak of monetarism based on modernisation theory as one development theory applicable to Africa. The phenomenal growth rates of post-war Germany and Japan after the infusion of capital through the Marshal Plan were quoted as success stories of monetarist ideology. Implied here is that most African leaders sought to catch up with the developed nations by taking advantage of their technology and the anticipated aid flows from the West.

In the 1950s and 1960s, newly independent African countries adopted a system of administration, labelled 'Development Administration' (DA). The DA enlisted Western experts to help with their models of bureaucratic organisation, training and technical assistance (Turner and Hulme, 1997:154). The DA movement was based on the assumption that " the primary obstacles to development are administrative rather than economic" (Doland Stone cited in Turner and Hulme, 1997:12). Thus, using ideas and mechanisms of the developed world, public administration could be instrumental in social and economic development in Africa. The main elements of DA were impartial management, bureaucratic rationality and neutrality, planning hierarchy, management by objectives, planning, programming and budgeting (PPB), civil service professionalism, centralised authority and job specialisation (Chanie, 2013: 8). DA was grounded on the concepts of development and classical administrative theories such as Taylor's scientific management theory, Fayol's administrative theory and the ideal type of bureaucratic forms of organisation.

Chanie (2013:8-9) summaries the DA specific reforms as follows: 


\section{MInstitute ${ }_{\text {Mnk }}^{\text {Macrothin }}$}

- Strengthen the centralised and interventionist state to plan and implement socio-economic development. The state-at-the-centre was accepted as the prime actor in bringing change and accelerating economic growth, to act as leader, investor, regulator, innovator (Turner and Hulme, 1997);

- Overhaul management of public finances, which included re-orienting the system of budgeting for development programmes and introducing performance budgeting with new accounting and analytical techniques (Chanie, 2013);

- Re-organise government agencies and their subdivisions in terms of specialisations planning boards, nation-building departments (agriculture, industry, education, health), public enterprises, farmers' organisation) and instituting a system of delegation and lines of communication in the government structure to permit effective and expeditious decisions and performance (Ibid.); and

- Introduce a model of devolved local government where sub national governments were expected to be constitutionally separated from the central government and were given powers such as revenue raising (Turner and Hulme, 1997:160).

However, these reforms' implementation, impact and outcomes were disappointing. By the late 1960s, it became clear that modernisation and the economic development strategies associated with it had failed. The empirical failings of modernisation prescriptions led to the loss of confidence in its validity. Nevertheless, in many of the African countries, the systems of government organisation, budgeting and personnel administration were structured according to the DA ethos and are still widely practised.

The dependency theory is in stark opposition to the modernisation paradigm. The dependency theory has been popularised in Africa through the writings of Walter Rodney (1972) and Amin (1976). The latter provides the most sustained and sophisticated analysis. Amin (1976) provides a categorisation of African economies into three groups: colonial trade economies, plantation economies and labour reserve economies. These three groups managed to point out the lopsided relationship between the centre and the periphery. Amin (1976) is adamant that unless African countries rupture their links to the world capitalist economy, their condition of underdevelopment is unlikely to change.

The dependency theory revolutionised the African thinking about development. The adoption of the Lagos Plan of Action (LPA) and Final Act Lagos (FAL) in April 1980 by the African Heads of State at their first-ever economic summit constituted (a) a reaction to the failures of modernisation and other orthodox developmental theories and strategies of the 1970s as well as (b) a response and commitment to redress the economic crisis that had plagued their continent since independence. The Lagos Plan of Action, also, owed its different thinking about development much to dependency theory, especially its emphasis on collective self-reliant development through the eventual creation of a continent-wide common market (Shaw, 1989).

In 1979, African Heads of State adopted the Monrovia Declaration which placed emphasis on collective self-reliance and regional linkages through (a) self-sufficiency in food; (b) a sound industrial base; (c) development of transportation and communications to facilitate regional 
internal integration and (d) increase in intra-African trade (Organisation for African Unity (OAU), 1979). The Monrovia Declaration concluded with a strong commitment on the part of African leaders to adhere to the agreed strategy:

We hold firmly to the view that these commitments will lead to the creation at the national, sub-regional and regional levels of a dynamic inter-dependent African economy band will thereby pave the way for the eventual establishment of an African Common Market leading to an African Economic Community (OAU, 1979).

Both the Monrovia Declaration and the LPA were comprehensive and realistic enough to offer hope for a better future for Africa if rigorously implemented. However, the two documents suffered from certain limitations. Neither of them addressed seriously the question of transforming fundamentally the political-economic and institutional structures that most African countries inherited after independence. The Lagos Plan of Action remained nothing more than an expression of African governments' stated long-term goals with little impact on the policies of individual countries.

However, the dependency theory laid the blame for Africa's problems on external factors thereby implicitly absolving the rulers of the continent of any blame. As Shaw advises, "the African states are not robots that merely react to 'external' inputs and instructions" (1982: 241). However, there were numerous internal factors that hindered effective development such as corruption, maladministration and bad governance.

Indeed, corruption is a major problem in Africa. Underscored is the assertion that state institutions are used to pursue personal goals rather than collective ones that are publicly proclaimed. The public sector is treated as a neo-patrimonial sector in which personal interest considerations override national objectives (Williame, 1972). In that perspective, the African state has become an instrument of personal advancement rather than a partner in development.

The Structural Adjustment Programmes (SAPs) became a dominant feature of economic management in Africa since the early 1980s. The two fundamental features of SAPs were: trade liberalisation and the reduction of government expenditure. Within the context of these two features lie several conditionalities that were considered critical for those targeted countries implementing structural adjustment programmes. These included: decontrolling of prices, deregulation of trade, devaluation of currency, reduction in public expenditure, wage restraints, privatisation, good governance, and human rights observance.

These austerity measures however caused political, social and economic havoc in most of the African country economies. Fiscal austerity in a period of economic policy adjustment, coupled with an absence of social safety nets for vulnerable groups also led to a rise in political and social instability. The SAPs also seriously eroded the ability of African states to provide essential services such as health, education and the much needed infrastructure.

Throughout the African continent, the pattern of sectoral adjustment in agriculture under the custody of the IMF-WB institutions had been unequivocally towards the destruction of food security. Dependency vis-à-vis the world market has been reinforced. Food aid to 
Sub-Saharan Africa increased by more than seven times since 1974 and commercial grain imports more than doubled. Grain imports for Sub-Saharan Africa expanded from 3.72 million tonnes in 1974 to 8.47 million tonnes in 1993. Food aid increased from 910000 tonnes in 1974 to 6.64 million tonnes in 1993 (World Bank, 1992; Food and Agricultural Organisation, 1993).

Under the structural adjustment programme, farmers increasingly abandoned traditional food crops. For example, Malawi which was once a net food exporter, maize production declined by 40 per cent in 1992 while tobacco output doubled between 1986 and 1993. One hundred and fifty thousand hectares of the best land was allocated to tobacco (Southern African Economist, 1993:51).

The SAPS were simply short-term financial crisis management techniques that failed to look ahead. The irony is that during the SAPs era, a group of countries from the traditional South (for example, China, Taiwan, Malaysia, Korea) were becoming increasingly industrialised and asserting themselves on the world stage. Furthermore, the BRICS countries (Brazil, Russia, India, China and South Africa) opened up a new window of collaboration and partnership for developmental programmes.

The claim that SAPs were an instrument designed to promote long-term and sustained economic growth has been challenged by critics. One observer has described SAPs as "economic genocide" programmes (Chossudovsky, 1997:37) carried out through the conscious and deliberate manipulation of market forces. The economic genocide description reveals that the social impacts of SAPs were devastating.

The criticisms led to the demands for a 'New World Order' where the IMF and WB were asked to review objectives and policies regarding structural adjustment. For Africa, after nearly two decades of failed SAPs, the New Partnership for Africa's Development (NEPAD) was founded in 2001 with a view to creating an African Union continental technical body that could address the development challenges facing the continent.

\section{Conclusion}

The history of the theory and practice of development shows development as a multifaceted process. One of the strengths of modernisation theory lies in its recognising the complex interconnections between cultural, economic, political and technological change. The road to development has not been as smooth as modernisation theorists predicted. As early as the 1960s, dependency theorists criticised their predictions as an ideological screen that concealed the exploitation of the poorer countries by the wealthier countries. From the dependency perspective, development was always a doomed project, condemned to fail as long as the economic bonds that tie the poorer countries to the richer countries remained secured. Wade (2004) argues that the gap between the rich who mainly reside in the North and the poor who largely live in the South "is a structural divide, not just a matter of a lag in the South's catch-up." This structural explanation for the failure of the development project contrasts with the answer that modernisation theory gives for lack of success - the failure of 
poorer countries to transform their traditional norms and attitudes, institutions, economy and political processes along modern lines.

Development in Africa was both affected by endogenous and exogenous factors. It cannot be denied that colonialism played a role in the social well-being and economic growth of Africa. The dependency theory identified colonialism as the external factor that impoverished the colonised countries. The title of Walter Rodney's (1972) book, How Europe Underdeveloped Africa, clearly implicates colonialism as the exogenous cause of the problem. This anti-colonialism view allows the governments of African nations to abrogate any responsibility for their actions. This explains why most African countries welcome China's strategy which is confined to promoting a new globalisation without hegemony - something which neither the United States of America nor Europe deem acceptable (Amin, 2011:12). However, internal factors have acted as a 'break' on the development of African countries (Harrison and Huntington, 2000).

According to Berger (1985: 12), most developmental problems in the poorer countries stemmed from internal causes, such as, "economic systems that stultify growth and impeded productivity; political corruption; oppression of people (to) the point where they cease to be economically active; persecution of economically productive minorities (such as the Asians in eastern Africa and the Chinese in southeast Asia); and, in some cases, indigenous social patterns and cultural values that are not conducive to economic activity." It is quite apparent that some of these factors highlighted above by Berger do explain some of the challenges development countries face in a cogent manner.

For many of the nations of Africa, Asia and Latin America, the post-colonial period could not be labelled independent because of the effective maintenance of the dependency structure by such economic tools as loans, aid, investments and trade conditions as set out by the IMF, the WB and other international financial institutions. This is what Amin (2011:62) calls "collective imperialism of the Triad (the United States, Europe, Japan)." This collective imperialism is articulated through the:

management of a world system by the common instruments of the Triad: at the economic level, by the World Trade Organisation (the colonial ministry of the Triad), the International Monetary Fund ( the colonial collective monetary agency), the World Bank (the propaganda ministry), the Organisation for Economic Cooperation and Development (OECD) and the European Union (constituted to prevent Europe from extricating itself from liberalism); and at the political level, by the $G 7 / G 8$, the armed forces of the United States and their subordinate instrument, NATO with the marginalisation/domestication of the United Nations completing the picture (Amin, 2011:62).

In general, there is profound disillusionment with the development theories that have been in vogue over the years. All major indicators of economic and social development show that Africa still lags behind the rest of the world in terms of economic development. Images of 
mass extreme poverty, famine, starvation, disease are prevalent in Africa especially in Sub-Saharan Africa. As African countries address development challenges facing them, they have an opportunity to critically access the shortcoming and benefits of the various development theories and in the process adopt those aspects offered by the theories that are relevant to their own development needs.

\section{References}

Amin, S. (2011). Ending the Crisis of Capitalism or Ending Capitalism? Cape Town: Pambazuka Press.

Amin, S. (2009). "Aid for Development?", in Abbas, Hakima and Niyiragira, Yves (eds.), Aid to Africa: Redeemer or Coloniser? Oxford: Pambazuka Press.

Amin, S. (1985). Delinking. New York: Monthly Review Press.

Amin, S. (1976). Unequal Development. Los Angeles: Harvest Press.

Baran, P.A. (1957). The Political Economy of Growth. New York: Monthly Review Press.

Bauer, P.T. (1984). Reality and Rhetoric: Studies in the Economics of Development. London: Weidenfield and Nicolson.

Berger, P. (1985). "Speaking to the Third World", in P. Berger and Novak, M., Essays on Development and Democracy. Washington, DC: American Enterprise Institute for Public Policy Research.

Bhagwati, J. (2005). In Defense of Globalisation: With A New Afterword. Oxford: Oxford University Press.

Chakaodza, J. M. (1993). Structural Adjustment in Zambia and Zimbabwe: Reconstructive or Destructive? Harare: Third World Publishing House (Pvt) Ltd.

Chanie, P. (2013). The Trajectory of Public Administration in Africa: Background, in Chanie, P. and Mihyo, P. B. (eds.), Thirty Years of Public Sector Reforms in Africa: Selected Country Experiences. Kampala: OSSREA and Fountain Publishers.

Chossudovsky, M. (1997). The Globalisation of Poverty: Impacts of IMF and World Bank Reforms. London and New Jersey: Zed Books Ltd.

d'Sousa, D. (2002). Two Cheers for Colonialism. The Chronicle of Higher Education, 10 May.

Easterly, W. (2002). The Elusive Quest for Growth. Cambridge, MA: MIT Press.

Emmanuel, A. (1972). Unequal Exchange: A Study of the Imperialism of Trade. New York: Monthly Review Books.

Escobar, A. (1995). Encountering Development: The Making and Unmaking of the Third World. Princeton, NJ: Princeton University Press. 
Food and Agricultural Organisation. (1993). Food Supply Situation and Crop Prospects in Sub-Saharan Africa. Special Report, No. 1, Rome: April.

Frank, A. G. (1971). Capitalism and Underdevelopment in Latin America. London: Penguin.

Frank, A. G. (1974). Lumpenbourgeiosie/Lumpendevelopment: Dependence, Class, and Politics in Latin America. New York: Monthly Review Press.

Fukuyama, F. (2006). After the NeoCons. London: Profile Books.

Gray, J. (2004). Heresies: Against Progress and Other Illusions. London: Granta Books.

Greig, A., Hume, D. and Turner, M. (2007). Challenging Global Inequality: Development Theory and Practice in the $21^{\text {st }}$ Century. Great Britain: Palgrave Macmillan.

Harris, N. (1987). The End of the Third World. London: Penguin.

Harrison, L. and Huntington, S. (2000). Culture Maters: How Values Shape Human Progress. New York: Basic Books.

Haut Commissariat (1992). des Nations Unies pour les refugies. Afrique austral, la secheresse du siècle, Geneva, July.

Hertz, N. (2004). IOU: The Debt Threat and Why We Must Defuse It. London: Fourth Estate.

Hoogvelt, A. (1997). Globalisation and the Postcolonial World: The New Political Economy of Development. Basingstoke: Macmillan. http://dx.doi.org/10.1007/978-1-349-25671-6

International Labour Organisation (2004). A Fair Globalisation? Creating Opportunities for All. Washington, DC: IMF.

Kothari, U. (2002). Feminist and Postcolonial Challenges to Development, in U. Kothari and M. Minogue (eds.), Development Theory and Practice: Critical Perspectives. Basingstoke: Palgrave.

Lal, D. (1985). The Poverty of Development Economics. Cambridge, Mass: Harvard University Press.

Landes, D. (2002). The Wealth and Poverty of Nations. London: Abacus Books.

Larrain, J. (1989). Theories of Development: Capitalism, Colonialism and Dependency. Cambridge: Polity Press.

Lerner, D. (1972). Modernisation: Social Aspects, in D. Sills (ed.), International Encyclopaedia of the Social Sciences, Vol. 9. New York: Collier Macmillan.

Lipietz, A. (1988). New Tendencies in the International Division of Labour: Regimes of Accumulation and Modes of Regulation, in A.J., Scott and M. Storper (eds), Production, Work, Territory: The Geographical Anatomy of Industrial Capitalism. Boston, MA: Unwin Hyman.

Marx, K., \& Engels, F. (1976). The German Ideology. Moscow: Progress Publishers. 
Minogue, M. (2002). Critical Perspectives on Development: An Introduction, in U. Kothari and M. Minogue (eds.), Development Theory and Practice: Critical Perspectives. Basingstoke: Palgrave.

Olsen, M. (1982). The Rise and Decline of Nations. New Haven, CT: Yale University Press.

Organisation of African Unity (OAU) (1979). Monrovia Strategy for the Development of Africa and the Declaration of Commitment. Monrovia.

Pieterse, G. (2009). Trends in Development: Pieterse 2e-3890-CH-01: Giulianotti-3852-Ch-01.qxp.qxp 5/6/2009 3:15 PM Page 1 (accessed 17 December 2015).

Pieterse, J. N. (2004). Globalisation or Empire? London: Routledge.

Power, M. (2003). Rethinking Development Geographies. London: Routledge.

Prebisch, R. (1971). Change and Development: Latin America's Great Task. New York: Praeger.

Rapley, J. (2002). Understanding Development: Theory and Practice in the Third World. Boulder, CO: Lynne Rienner.

Rodney, W. (1972). How Europe Underdeveloped Africa. London: Bogle-L'Ouver- ture Publications.

Sachs, J. (2005). The End of Poverty: How We Can Make It Happen In Our Lifetime. London: Penguin.

Shaw, T. (1989). The Revival of Regionalism in Africa: Cure for Crisis or Prescriptions for Conflict? The Jerusalem Journal of International Relations, 11(4).

Shaw, T. (1982). Beyond Neo-Colonialism: Varieties of Corporatism in Africa. Journal of Modern African Studies, 2(2). http://dx.doi.org/10.1017/s0022278x00024460

Southern African Economist, 1993:51: http://books.google.co.zw/b. Accessed 31 January 2016.

Taylor, L. (1997). The Revival of the Liberal Creed: The IMF and the World Bank in a Globalised Economy. World Development, 145-152. http://dx.doi.org/10.1016/S0305-750X(96)00117-9

Turner, M., \& Hulme, D. (1997). Governance Administration and Development: Making the State Work. London: Macmillan Press Limited. http://dx.doi.org/10.1007/978-1-349-25675-4

Valenzuela, J. S., \& Valenzuela, A. (1978). Modernisation and Dependency: Alternative Perspectives in the Study of Latin American Development. Comparative Politics, 104.

Wachtel, H. (1986). The Money Mandarins: The Making of a New Supranational Economic Order. New York: Pantheon Books.

Wade, R. (2004). Is Globalisation Reducing Poverty and Inequality? World Development, 32(4). http://dx.doi.org/10.1016/j.worlddev.2003.10.007 


\section{Macrothink}

International Journal of Social Science Research

ISSN 2327-5510 2016, Vol. 4, No. 1

Wallerstein, I. (2004). World Systems Analysis: An Introduction. Durham, NC: Duke University Press.

Webster, A. (1984). Introduction to the Sociology of Development. Basingstoke: Macmillan. http://dx.doi.org/10.1007/978-1-349-17667-0

Wertheim, W. F. (1974). Evolution and Revolution. Penguin.

Williame, J. C. (1984). State and Society in Africa. London: Totawa, N. J, Cass and Co.

Wright, R. (2005). A Short History of Progress. Melbourne: Text Publishing.

World Bank. (1992). World Development Report. Washington D.C: The World Bank.

\section{Copyright Disclaimer}

Copyright for this article is retained by the author(s), with first publication rights granted to the journal.

This is an open-access article distributed under the terms and conditions of the Creative Commons Attribution license (http://creativecommons.org/licenses/by/3.0/). 